\title{
Muhafazakâr Tutumların Reklamlara Yönelik Tutumlar Üzerindeki Etkileri
}

\author{
Fatma Uçar (Dr. Öğr. Üyesi) \\ Pamukkale Üniversitesi İletişim Fakültesi \\ fucar@pau.edu.tr \\ Orcid: 0000-0002-4288-6124
}

Başvuru Tarihi: 21.01.2019

Yayına Kabul Tarihi: 12.04.2019

Yayınlanma Tarihi: 22.07.2019

DOI: 10.17680/erciyesiletisim.515888

Uçar, F. (2019). Muhafazakâr Tutumların Reklamlara Yönelik Tutumlar Üzerindeki Etkileri. Erciyes İletişim Dergisi, 6 (2), 1577-1596. DOI: 10.17680/erciyesiletisim.515888

\section{Öz}

Türkiye'de 1980'li yıllardan itibaren neo-liberal ekonomi politikalarının kabul edilmesi ile tüketim toplumuna dönüşme süreci başlamış; 2000’li yıllardan sonra ise muhafazakarlık kapitalist sisteme iyice adapte olmuştur. Günümüz Türkiye'sinde sıklıkla tartışılan bir kavram haline gelen muhafazakarlık konusunda ise iki ana yaklaşım vardır. Bunlardan ilki muhafazakarlığı siyasi bir ideoloji olarak görürken diğeri onu kișisel bir eğilim, bir tutum olarak ele almaktadır. Diğer tüm tutumlar gibi muhafazakâr tutumlar da bireyin davranışlarını yönlendiren unsurlardan biridir. 80'li yıllardan bu yana Türkiye'nin yaşamakta olduğu değişim ve dönüşüm süreci göz önünde bulundurulduğunda tüketim toplumunun ayrılmaz bir parçası olan reklamlar ile bireylerin sahip olduğu muhafazakâr tutumlar arasında nasıl bir ilişki olduğu sorusu bu araștırmanın ana çıkış noktasını oluşturmaktadır. $\mathrm{Bu}$ bağlamda, bu araștırma kapsamında muhafazakarlık, tutum olarak ele alınmıș ve kişilerin sahip olduğu muhafazakâr tutumların reklama yönelik tutumlar üzerinde belirleyici olup olmadığı ortaya konmaya çalışılmıștır. Bu amaç doğrultusunda 250 kişiye anket uygulanarak muhafazakarlık düzeyi ile reklamlara, reklamcılığa yönelik genel tutumlar ve maruz kalınan belirli bir reklama yönelik tutumlar arasındaki ilişki incelenmiştir. Araştırma sonuçları muhafazakarlık düzeyi arttıkça reklama ve reklamcılığa yönelik tutumların olumlu yönde değiștiğini ortaya koymuştur. Maruz kalınan belirli bir reklam (Ford Kamyon 8 Mart Dünya Kadınlar Günü reklamı) özelinde ise ilgili reklama yönelik tutum ve muhafazakarlık ilişkisinde cinsiyet değişkeninin belirleyici olduğu tespit edilmiştir. Muhafazakarlık düzeyi arttıkça reklama ve reklamcılığa yönelik genel tutumların olumlu yönde değişmesi ise muhafazakarlığın kapitalist sisteme uyumunun bir yansıması olarak anlamlandırılmıştır.

Anahtar Kelimeler: Muhafazakâr Tutumlar, Muhafazakarlık, Reklamlar, Reklamcılığa Yönelik Tutumlar.

\footnotetext{
* Bu çalıșma, Anadolu Üniversitesi Sosyal Bilimler Enstitüsü’ne 2017 yılında sunulan ve Anadolu Üniversitesi Bilimsel Araștırmalar Komisyonunca destelenmiş (Proje no: 1407 E 361) "Muhafazakarlık ve Reklamlar: Muhafazakar Tutumların Reklam Kodaçımlama ve Reklamlara Yönelik Tutumlar Üzerindeki Etkileri başlıklı Doktora tezinin özetidir.
} 


\title{
The Effects of Conservative Attitudes on Attitudes towards Advertising*
}

\author{
Fatma Uçar (Asst. Prof. Dr.) \\ Pamukkale University Faculty of Communication \\ fucar@pau.edu.tr
}

Orcid: 0000-0002-4288-6124

Date Received: 21.01.2019

Date Accepted: 12.04.2019

Date Published: 22.07.2019

DOI: 10.17680/erciyesiletisim.515888

\begin{abstract}
The adoption of neo-liberal economic policies in Turkey as of 1980s triggered a quick transformation into a consumer society; and, in the early 2000s, "conservatism" widely adapted itself into the capitalist system. There are mainly two approaches to conservatism, which is a frequently discussed issue in today's Turkey. While the first approach considers conservatism a political ideology, it is a personal preference and attitude according to the second one. Just like other attitudes, conservative attitudes are one of the factors that shape individuals' behaviors. It is a well-known fact that Turkey experienced a radical transformation as of 1980s and certain changes depending on this transformation. Accordingly, this study aims to explore the relationship between conservative attitudes of individuals and advertisements, which are the indispensable components of consumer society. Thus, "conservatism" was taken as an attitude in this study, which aims to find out whether individuals' conservative attitudes predict their attitudes towards advertisements or not. For the purposes of this study, the researcher administered a survey to 250 people to examine the relationship between conservatism, general attitude towards advertisements and advertising and the attitude towards a specific advertisement that the participants were exposed to. The results of the study showed that as the level of conservatism increases, the attitudes towards advertisements and advertising change in a positive way. As for the specific commercial the participants were exposed to (Ford Trucks commercial celebrating March 8th Women's Day), the study found that gender is a predicting factor for the relationship between attitudes towards this specific advertisement and conservatism. Finally, it is believed that increasingly more positive general attitude towards advertisement and advertising as the level of conservatism increases reflects the adaptation of conservatism to the capitalist system.
\end{abstract}

Keywords: Conservative Attitudes, Conservatism, Advertisements, Attitudes Towards Advertising.

*This study is supported by Anadolu University Scientific Research Commission (Project no: 1407 E 361) and a part of PhD dissertation written by Fatma Uçar in 2017. 


\section{Giriş}

Günümüzde sıklıkla tartışılan kavramlardan biri haline gelen muhafazakarlık, bir yandan siyasi bir ideolojiyi temsil ederken diğer taraftan bireysel bir eğilim, bir tutum olma özelliğini taşımaktadır (Bora ve Onaran, 2004, 234; Çaha, 2001, 97-98; Ergil, 1989, 270; Mollaer, 2009, 30; Safi, 2007, 31; Vural, 2011, 41).

1980’li yıllardan itibaren sağ siyasi yönetimlerce neo-liberal ekonomi politikalarının kabul edilmesi ile Türkiye'nin piyasa değerlerine adapte olduğu ve toplumun tüketim toplumuna dönüştüğ̈̈; 2000'li yıllardan sonra ise muhafazakarlığın kapitalist sisteme iyice entegre olduğu görülmektedir (Durak, 2013, 34; Yankaya, 2014, 16; Demirezen, 2015, 78-79). Bu gelișmelerin yanında yapılan araştırmalar Türkiye'de yaşayan bireylerin ağırlıklı olarak muhafazakâr olduğunu ortaya koymaktadır (Esmer, 2012; Yllmaz, 2006, 2012).

Diğer tüm tutumlar gibi muhafazakâr tutumların da bireylerin yaşama karşı duruşlarında yönlendirici bir etkisi olduğunu söylemek yanlıș olmaz. Söz konusu reklamlar olduğunda ise bireylerin sahip oldukları muhafazakâr tutumların sürece nasıl dahil olduğu bilinmemektedir. 80'li yıllardan bu yana Türkiye'nin yaşamakta olduğu değişim ve dönüşüm süreci de göz önünde bulundurulduğunda tüketim toplumunun ayrılmaz bir parçası olan reklamlar ile bireylerin sahip oldukları muhafazakâr tutumlar arasında nasıl bir ilişki olduğu sorusu bu araștırmanın ana çıkış noktasını oluşturmaktadır. Yapılan alanyazın incelemesinde bireylerin sahip olduğu muhafazakâr tutumlar ile reklamlar arasındaki ilişkiyi inceleyen herhangi bir çalıșmaya rastlanmamıştır. Farklı muhafazakarlık düzeyine sahip bireylerin reklamlara, reklamcılığa ve maruz kalınan belirli bir reklama yönelik tutumlarında muhafazakarlık düzeyine göre bir farklılaşmanın olup olmadığı konusu belirsizliğini korumaktadır.

\section{Alanyazın}

\subsection{Reklamcılığa, Reklamlara ve Reklama Yönelik Tutum Farkları}

Tutum bireyin herhangi bir șeye karşı hazır oluş durumu olarak tanımlanmaktadır (Arkonaç, 1998, 170; İnceoğlu, 2011, 22-2; Tavşancıl, 2006, 65). Reklamların hedeflerine ulaşıp ulaşmamasında da izleyicinin sahip olduğu tutumların reklamların başarısı üzerinde belirleyici olduğu söylenebilir.

Reklam ve tutumlar konusunda önemli bir nokta da bir kurum olarak reklamcllığa, iletişim aracı olarak reklama ve maruz kalınan belirli bir reklama yönelik tutumlar arasındaki ilişkilerdir.

MacKenzie ve Lutz $(1989,53)$ reklamlara yönelik genel tutumu, reklama yönelik tutarlı bir şekilde olumlu ya da olumsuz tepki verme yönünde öğrenilmiş bir yatkınlık olarak tanımlamışlar ve bireyin belirli bir reklama yönelik tutumunun olumlu ya da olumsuz olmasının reklam sonucunda ortaya çıkan davranışı belirlediğini dile getirmişlerdir. Reklama yönelik tutumu ise belirli bir reklam uyaranına karşı, reklama maruz kalma sırasında olumlu ya da olumsuz yönde tepki verme eğilimi şeklinde tanımlamışlardır (McKenzie ve Lutz, 1989, 49).

Mehta $(2000,67)$ tüketicilerin reklamlara yönelikgenel tutumunun reklamın etkililiği üzerinde belirleyici unsurlardan birisi olduğunu, çünkü tüketicilerin reklama yönelik biliş düzeylerinin tüketicilerin düşünce ve duygularını, en nihayetinde de reklama 
yönelik tutumlarını da etkileyeceğini dile getirmiștir. Tüketicilerin reklamlara yönelik inançları markaya yönelik tutum ve satın alma niyeti üzerinde belirleyici bir değişken iken (Mackenzie ve Lutz, 1989; Lutz, 1985, 53) ve reklama yönelik olumsuz tutumlar da reklamın iletişim etkisini kesintiye uğratan bir unsurdur (Calfee ve Ringold, 1988; Pollay ve Mittal, 1993).

Lutz ve diğerleri (1983'ten aktaran: Mckenzie ve Lutz, 1989, 50) bir kurum olarak reklamcllı̆̆a yönelik genel tutumun reklamlara yönelik genel tutum üzerinde ana belirleyicilerden biri olduğunu söylemektedir. Kurum olarak reklamcılı̆g yönelik genel tutumlar, bir iletişim aracı olarak reklama yönelik genel tutumlar üzerinde belirleyici olurken; belirli bir reklama yönelik tutum ise markaya yönelik tutum ve satın alma niyeti üzerinde belirleyicidir (Mckenzie ve Lutz, 1989). Sandage ve Leckenby $(1980,29)$ de bir iletişim aracı olarak reklama ve kurum olarak reklamcılığa yönelik tutumlar arasındaki farka dikkat çekmişlerdir. Bir kurum olarak reklamcılık, reklamın toplum için oynadığı rolleri temsil eder, reklamların etkileri ve amacı çerçevesinde tanımlanır. Bir iletişim aracı olarak reklam ise reklam uygulamalarına karşılık gelmektedir. Araştırmacılar bu iki boyutun reklama yönelik tutumlar üzerinde belirleyici olduğunu ileri sürmüșlerdir. Ancak bununla birlikte, reklama yönelik tutumların reklamcılık hakkındaki inançlar incelenmeksizin ortaya konamayacağını ifade etmişlerdir.

Kurum olarak reklamcılığa yönelik tutumlar ile bir iletişim aracı olarak reklama yönelik tutumları ayrı ayrı inceleyen araştırmaların sonuçları ise çoğunlukla bir kurum olarak reklamcllı̆a yönelik tutumların reklam uygulamalarına yönelik tutumlardan daha olumlu olduğu sonucunu ortaya koymuştur (Andrews ve diğerleri, 1994; Bir ve diğerleri, 2015; Petrovici ve Marinov 2007; Sandage ve Leckenby, 1980).

\subsection{Muhafazakarlık Nedir?}

Muhafazakarlık söz konusu olduğunda üzerinde uzlaşılmış bir tanım bulmak güçtür. "Muhafazakarlık terimi hem Türkçe hem de Batı dillerinde kullanılış şekliyle 'muhafaza etme' ya da 'bir şeyi bozulmadan koruma' (conserve) kökünden gelmektedir (Vural, 2011: 7)”. "Muhafazakarlık a) Politik- kültürel açıdan: reaksiyonerlik, tutuculuk, gericilik, cemaatçilik, doğuculuk; b) teolojik açıdan: dindarlık, öte dünyacılık, İslamcılık, mürtecilik; c) sosyolojik açıdan: geleneksellik/ geleneksel toplum, tarihsel durağanlık, az gelişmişlik, kırsallık (Mollaer, 2011, 59)" vb. olarak tanımlanabilmektedir. Diğer yandan "muhafazakarlık, liberalizm ve sosyalizm ile birlikte Batı'da son iki yüzyılın temel üç siyasal ideolojilerinden birisidir (Nisbet, 2011, 18)".

Muhafazakarlığın geçmişi Eflatun'a ve hatta insanlığın başlangıcına kadar uzansa da (Akkaş, 2004, 21) muhafazakâr düşüncenin temelleri 18. yüzyılda Aydınlanma Çăğ'ndan ve bunu takip eden büyük ekonomik, toplumsal ve siyasi çalkantıların eleştirisine dayanır. Muhafazakarlık, hümanizmle birlikte gelişen Rönesans ve Reform hareketlerinin, tanrı egemenliğinin insan egemenliğiyle yer değiştirmesinin, Aydınlanma Dönemi ve onun siyasi yansıması Fransız Devrimi ve evrenin, akılla tasarlanması düşüncesi sonucunda ortaya çıkan bir düşünce geleneği ve ideoloji olarak ortaya çıkmıştır (Akkaş, 2004, 21; Özipek, 2004, 72-73). Ancak modern anlamı ile bilinçli muhafazakarlık, 1790'da Edmund Burke'ün Reflections on the Revoulution in France isimli eserinin yayınlanışına kadar kendini göstermemiştir (Kirk, 1986'dan aktaran: Akıncl, 2012, 54). 
18. yüzyılda muhafazakarlığın ortaya çıkmasını etkileyen üç tarihsel olgudan söz edilmektedir: geleneğin yerine aklı esas alan, rasyonalizme dayalı Aydınlanma düşüncesi; toplumların değişimine hız kazandıran Fransız Devrimi ve değişmenin kural halini aldığı, emek yoğun teknolojiden sermaye yoğun teknolojiye geçişin yaşandığı Sanayi Devrimidir (Ergil, 1989, 269).

\subsubsection{Tutum mu İdeoloji mi?}

Muhafazakarlık, konusundaki iki görüşten ilki muhafazakarlığı Fransız Devrimi sonucunda ortaya çıkmış, yeni rejimin getirdiği modern kurum ve değerlere karşıt olan bir ideoloji olarak görmektedir. İkinci görüş ise muhafazakarlığı bir ideolojiden ziyade ana eğilimi, var olan kurum ve ilişkileri korumak olan dünyayı algılama, bir davranış biçimi ve eğilim olarak görmektedir (Safi, 2007, 31; Vural, 2011, 41). Muhafazakarlığı tanımlayan görüşlerden ilki muhafazakarlığı tarihin içine çekmeye çalışırken; ikinci görüş onu tarih dışı bir fenomen olarak tanımlamaktadır. İlk görüş, modernliğin temeli kabul edilen Aydınlanma ve Devrime karşı muhafazakarlığın muhalefet etmesinin, muhafazakarlığı zorunlu olarak tarihe ve ideolojilerin dünyasına dahil etmektedir. İkinci görüş ise, muhafazakarlığı insan türünde var olan evrensel tutumlara gönderme yaparak açıklamaktadır (Mollaer, 2009, 29-30).

Batı'daki muhafazakarlığın aksine Türkiye'deki muhafazakarlığın ideolojik boyutu zayıf olmakla birlikte toplumun sahip olduğu kültür, muhafazakâr tavrı etkilemektedir. Bu sebeple Türkiye'de muhafazakarlık Batı'daki gibi ideoloji olarak değil kültürel bir tutum olarak ele alınmalıdır (Şahin, 2010, 314).

Türkiye'de yaşayan bireylerin muhafazakarlığını ölçmeye yönelik yapılan çalışmalar arasında Prof. Dr. Yılmaz Esmer'in yürütücülüğünü yaptığı Türkiye Değerler Araștırması (2012) ile 2006 ve 2012 yıllarında Prof. Dr. Hakan Yılmaz tarafından gerçekleştirilen 'Türkiye'de Muhafazakarlık: Aile, Din, Batı" adlı araştırma önemli kaynaklardır. Yapılan araştırmalar (Esmer, 2012; Yılmaz 2006 ve 2012) Türkiye'de yaşayan bireylerin çoğunlukla muhafazakâr eğilime sahip olduklarını ortaya koymuştur. Bu muhafazakâr eğilimlerin şekillenmesinde ise aile, kadının toplumsal rolü, gelenekler, din, cinsellik, milliyetçilik ve siyasi eğilimler belirleyici unsurlar olarak karşımıza çıkmaktadır.

Türkiye'de yaşayan bireylerin çoğunluğunun muhafazakâr eğilime sahip olmalarının yanında diğer yandan 1980’li yıllardan itibaren sağ siyasi yönetimlerce neo-liberal ekonomi politikalarının kabul edilmesi ile Türkiye'nin piyasa değerlerine adapte olduğu ve toplumun tüketim toplumuna dönüștüğ̈; 2000'li yıllardan sonra ise muhafazakarlığın kapitalist sisteme iyice entegre olduğu görülmektedir (Demirezen, 2015, 78-79; Durak, 2013, 34; Yankaya, 2014, 16;). Dolayısıyla Türkiye örneğinde muhafazakâr ve kapitalist değerlerin bir arada varlıklarını sürdüğünü söylemek yanlış olmaz.

\section{Amaç}

$\mathrm{Bu}$ araştırmanın amacı, muhafazakâr tutumlar ile reklama yönelik tutumlar arasında ilişki olup olmadığını ortaya koymaktır. Bu bağlamda, bu çalışmada, bireylerin muhafazakarlık düzeylerine göre reklamlara yönelik tutumlarının nasıl şekillendiği incelenmiştir. $\mathrm{Bu}$ amaç doğrultusunda, araştırma kapsamında şu sorulara yanıt aranmıștır: 
1. Katılımcıların muhafazakarlık düzeyine göre iletişim aracı olarak reklama yönelik genel tutumları arasında bir fark var mıdır?

2. Katılımcıların muhafazakarlık düzeyine göre kurum olarak reklamcılığa yönelik genel tutumları arasında bir fark var mıdır?

3. Katılımcıların muhafazakarlık düzeyine göre Ford Kamyon reklamına yönelik tutumları arasında bir fark var mıdır?

a. Kadın katılımcıların muhafazakarlık düzeyine göre Ford Kamyon reklamına yönelik tutumları arasında fark var mıdır?

b. Erkek katılımcıların muhafazakarlık düzeyine göre Ford Kamyon reklamına yönelik tutumları arasında fark var mıdır?

4. Katılımcıların Ford Kamyon reklamında rahatsız oldukları unsurlar nelerdir?

a. Muhafazakarlık düzeylerine göre katılımcıların Ford Kamyon reklamında rahatsız oldukları unsurlar nelerdir?

5. Katılımcıların Ford Kamyon reklamında hoşlarına giden unsurlar nelerdir?

a. Muhafazakarlık düzeylerine göre katılımcıların Ford Kamyon reklamında hoşlarına giden unsurlar nelerdir?

\section{Yöntem}

$\mathrm{Bu}$ araştırmada olabildiğince farklı muhafazakarlık düzeyinden bireye ulașılmaya çalışılmıştır. Örneklemin heterojen olması önem arz etmesinden dolayı araştırmaya dahil olan bireyler amaçlı örnekleme yöntemlerinden heterojenlik örneklemi esas alınarak seçilmiştir. Anket uygulaması Eskișehir'de yaşayan ve on sekiz yaş üstü 250 kişiden oluşan bir çalışma kümesi ile gerçekleştirilmiştir.

Veriler yüz yüze anket yöntemi ile toplanmıştır. Anketin ilk bölümü kurum olarak reklamcılığa yönelik genel tutum ölçeği ve bir iletişim aracı olarak reklamlara yönelik genel tutum ölçeğinden (Sandage ve Leckenby, 1980) oluşmaktadır. İkinci bölümde Ford Kamyon reklamına yönelik tutum ölçeği (Donthu, 1998) ile katılımcıların izledikleri reklamda hoşlarına giden ve rahatsız oldukları unsurları belirlemeye yönelik iki adet açık uçlu soru bulunmakta, üçüncü bölümde ise Muhafazakarlık Ölçeği (Wilson ve Petterson, 1968'den aktaran: Wilson, 2013, 52) yer almaktadır. Anketin son bölümünde katılımcıların demografik bilgilerine yönelik sorular bulunmaktadır.

Muhafazakarlık Ölçeği (C Scale) (Wilson, 2013, 52) ve maruz kalınan belirli bir reklama yönelik tutum ölçeği (Donthu, 1998) ölçek uyarlama ilkeleri doğrultusunda Türkçe'ye uyarlanmıştır. Sandage ve Leckenby'ın (1980) reklamcılığa ve reklamlara yönelik genel tutum ölçeğinin Türkçe uyarlaması ise Bir ve diğerlerinin (2015) çalışmasından alınmıştır. Sonrasında tüm ölçeklerin güvenilirliğini test etmek amacıyla otuz kişinin katılımı ile bir pilot çalışma gerçekleştirilmiş, gerekli düzeltmeler yapılmıștır. Ölçeklerin güvenilirlik şartını sağladığı tespit edilmiştir.

Kurum olarak reklamcılığa ${ }^{1}$ ve iletişim aracı olarak reklama² yönelik genel tutum ölçeği ile belirli bir reklama (Ford Kamyon 8 Mart Dünya Kadınlar Günü reklamı) ${ }^{3}$ yönelik tutum ölçekleri semantik farklılıklar ölçeği formatındadır. Katılımcılardan ölçeklerde yer alan sıfatlara bir ila beş arasında bir puan vererek görüşlerini belirtmeleri istenmiştir.

Türkiye'de muhafazakarlığı belirlemeye yönelik yapılan araștırmalar kadının toplumsal cinsiyet rolleri hakkında aydınlatıcı bilgiler sunmaktadır. Yılmaz'ın 
(2012) araştırma sonuçlarına göre, Türkiye'de muhafazakarlık anlayışı, kadının aile içerisindeki eş ve anne olarak rolüne ilişkin tutumlar etrafında şekillenmektedir. “Türkiye'de ideal kadın erkeklerle hukuken eşit; gerektiğinde çalışıp para da kazanan, ama aile içerisindeki anne ve eş rollerini asla aksatmayan ve ev içi görevlerini aksatıyorsa işini bırakan ve namus kodlarının dışına çıkarak kocasının şerefine halel getirmeyen bir kadın tipidir (Yılmaz, 2012, 48)”. Esmer'in (2012) araştırma sonuçlarına göre ise Türkiye'de yaşayan bireylerin çoğunluğu aile reisinin erkek olduğunu ve kadının kocasına itaat etmesi gerektiğini; eğer ülkede ișsizlik varsa çalışmanın kadınlardan çok erkeklerin hakkı olduğunu, erkeklerin kadınlardan daha iyi şirket yöneticisi olduğunu ve bir annenin çalışmasının çocuklarına zarar vereceğini düşünmektedirler. Bu veriler ışığında araştırma kapsamında toplumsal cinsiyet rolleri içeren bir reklamın seçilmesinin uygun olacağına kanaat getirilmiş ve Ford Kamyon 8 Mart Dünya Kadınlar Günü televizyon reklamı araştırma için, uzman görüşleri arasında uzlaşma sağlanarak uygun bulunmuştur (Ford Kamyon reklam linki: https://www.youtube.com/watch?v=E1essuezzTo).

Toplam 24 maddeden ${ }^{4}$ oluşan Muhafazakarlık Ölçeğinde 13 adet liberal, 11 adet muhafazakâr madde bulunmaktadır. Ölçek maddeleri veri giriși yapılırken "Hayır, kabul edilmez" seçeneği 0; "Evet, kabul edilebilir" seçeneği 2, "Ne kabul edilebilir ne edilemez" seçeneği ise 1 olarak kodlanmış; sonrasında ise liberal maddeler için ters kodlama yapılmıștır (reverse coded). Böylece, bu ölçeğe göre bir kişinin alabileceği azami muhafazakarlık puanı 48 olarak tespit edilmiştir. Sonrasına her katılımcının aldığı puan 100'e oranlanarak tekrar hesaplanmıștır.

Araştırmada anket uygulamasından elde edilen veriler bilgisayara aktarılmış ve SPSS 13.0 (Sosyal Bilimler için İstatistik Programı) ile analiz edilmiştir. Verilerin analizinde katılımcılar muhafazakarlık düzeylerine göre düşük, orta ve yüksek olmak üzere üç gruba ayrılmış ve analizler bu şekilde gerçekleştirilmiştir. Anket formunda yer alan Ford Kamyon reklamında katılımcıların rahatsız oldukları ve hoşlarına giden unsurlar kodlanarak içerik analizi yöntemi ile analiz edilmiş ve frekans tabloları şeklinde sunulmuştur.

$\mathrm{Bu}$ araştırmada muhafazakarlığın siyasal bir ideoloji olmasının yanı sıra bireyin davranışlarına yön veren bir tutum olduğu varsayılmış ve şu noktalar ise birer sınırlık olarak kabul edilmiştir:

- Bu araştırma Ford Kamyon 8 Mart Dünya Kadınlar Günü televizyon reklamı ile sinirlidir.

- Bu araştırma kapsamında muhafazakarlık bireysel bir tutum olarak ele alınmış olup muhafazakarlığın siyasi ideoloji boyutu araştırma kapsamının dışındadır.

- Araştırmaya dahil olan katılımcıların olasılıklı olmayan amaçlı örnekleme yöntemi ile belirlenmiş olmasından dolayı araștırmanın bulguları evrene genellenemez.

- Muhafazakarlık ölçümleri Wilson ve Petterson'un muhafazakarlık ölçeği (C Scale), Ford Kamyon reklamına yönelik tutum ölçümleri Donthu'nun (1998) tutum ölçeği, kurum olarak reklamcılığa ve iletişim aracı olarak reklama yönelik tutum ölçümleri ise Bir ve diğerlerinin (2015) çalışmalarında Türkçe’ye uyarladıkları Sandage ve Leckenby'nin (1980) ölçeği ile sınırlıdır. 
Çalışmaya özgü tanımlar şu şekildedir:

Reklamcılığa yönelik genel tutum: Bir kurum olarak reklamcılığa yönelik genel tutumdur.

Reklama/lara yönelik genel tutum: Bir iletişim aracı olarak reklam uygulamalarına yönelik genel tutumdur.

Belirli bir reklama yönelik tutum: Belirli bir reklama yönelik, kişinin reklama maruz kalması sonucunda ortaya çıkan, kişinin sahip olduğu tutumdur.

Muhafazakarlık puanı/düzeyi: $\mathrm{Bu}$ çalışmada muhafazakarlık puanı/düzeyi katılımcıların Wilson ve Petterson'un geliştirdikleri Muhafazakarlık Ölçeğinin (C Scale) Türkçe uyarlamasına vermiş oldukları yanıtların 100 puana oranlanması ile elde edilen puanı ifade etmektedir. Düşük, orta ve yüksek muhafazakarlık puan aralıkları şu şekilde tanımlanmıştır:

- Düşük muhafazakarlık düzeyi/puanı: 0 ila 40 puan aralığı.

- Orta muhafazakarlık düzeyi/puanı: 41 ila 60 puan aralığı

- Yüksek muhafazakarlık düzeyi/puanı: 61 ila 100 puan aralığı

\section{Bulgular}

\section{1. Çalışma Kümesi Özellikleri}

Anket toplam 250 kişiye uygulanmış olup çalışma kümesi özellikleri Tablo 1'de yer almaktadır.

Tablo 1: Katılımcıların Demografik Özellikleri

\begin{tabular}{|c|c|c|c|}
\hline \multicolumn{2}{|c|}{ Demografik Özellikler } & \multirow{2}{*}{$\frac{\mathbf{N}}{125}$} & \multirow{2}{*}{$\begin{array}{c}\% \\
50 \\
\end{array}$} \\
\hline Cinciut & Kadın & & \\
\hline 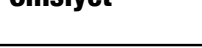 & Erkek & 125 & 50 \\
\hline \multirow{5}{*}{ Yaş } & $18-30$ & 80 & 32 \\
\hline & $31-40$ & 77 & 30,8 \\
\hline & $41-50$ & 62 & 24,8 \\
\hline & 51 ve üzeri & 30 & 12 \\
\hline & Kayıp veri & 1 & 0,4 \\
\hline \multirow{6}{*}{ Eğitim } & İlkokul & 38 & 15,2 \\
\hline & Ortaokul & 20 & 8 \\
\hline & Lise & 63 & 25,2 \\
\hline & Lisans & 82 & 32,8 \\
\hline & Lisansüstü & 40 & 16 \\
\hline & Kayıp veri & 7 & 2,8 \\
\hline \multirow{5}{*}{ Toplam Gelir } & 1.500 TL veya daha düsük & 69 & 27,6 \\
\hline & $1.501-3.000 \mathrm{TL}$ & 78 & 31,2 \\
\hline & $3.001-4.500 \mathrm{TL}$ & 46 & 18,4 \\
\hline & 4.501 TL'den yüksek & 56 & 22,4 \\
\hline & Kayıp veri & 1 & 0,4 \\
\hline \multirow{2}{*}{ Medeni durum } & Evli & 88 & 35,2 \\
\hline & Bekar & 162 & 64,8 \\
\hline
\end{tabular}

Araştırma kapsamında kullanılan ölçeklerin Cronbach Alpha değerleri şu şekilde tespit edilmiştir: Muhafazakarlık Ölçeği Cronbach Alpha değeri 0,933; Kurum Olarak Reklama Yönelik Tutum Ölçeği Cronbach Alpha değeri 0,686; İletişim Aracı Olarak 
Reklama Yönelik Genel Tutum Ölçeği Cronbach Alpha değeri 0,729; Ford Kamyon Reklamına Yönelik Tutum Ölçeği Cronbach Alpha değeri 0,929.

"0,60 ile 0,80 arasındaki Cronbach Alpha katsayısı ölçeğin oldukça güvenilir olduğunu; 0,80 ve üzeri bir katsayı ise ölçeğin yüksek derecede güvenilir bir ölçek olduğunu göstermektedir (Kalaycı, 2010, 405)." Bu veriler ışığında, bu araştırma kapsamında kullanılan ölçeklerin güvenilirlik şartını sağladığı söylenebilir.

\subsection{Muhafazakarlık Düzeyine Göre İletişim Aracı Olarak Reklama Yönelik Genel Tutumlar}

Katılımcıların muhafazakarlık düzeyine göre iletișim aracı olarak reklama yönelik genel tutumları arasında bir fark olup olmadığını ve eğer fark varsa bunun hangi gruplar arasında olduğunu ortaya koymak amacıyla Tek Yönlü ANOVA analizi yapılmıştır. ANOVA Tablosunda yer alan p değeri (Sig) 0,05'ten küçük olduğu için katılımcıların muhafazakarlık düzeylerine göre iletişim aracı olarak reklama yönelik genel tutumları açısından gruplar arasında farklılık olduğu söylenebilir (Tablo 2).

Tablo 2: İletişim Aracı Olarak Reklama Yönelik Tutum

\begin{tabular}{|l|c|c|c|c|c|}
\hline $\begin{array}{l}\text { İletişim Aracı Olarak Reklamcılığa } \\
\text { Yönelik Genel Tutum }\end{array}$ & $\begin{array}{c}\text { Sum of } \\
\text { Squares }\end{array}$ & df & $\begin{array}{c}\text { Mean } \\
\text { Square }\end{array}$ & F & Sig. \\
\hline Between Groups & 21,584 & 2 & 10,792 & 17,793 &, 000 \\
\hline Within Groups & 147,992 & 244 &, 607 & & \\
\hline Total & 169,576 & 246 & & & \\
\hline$* P \leq 0,05$
\end{tabular}

Çoklu Karşılaştırmalar Tablosuna göre orta ve yüksek muhafazakarlık puanına sahip katılımcıların iletişim aracı olarak reklama yönelik genel tutumlarının, düşük muhafazakarlık puanına sahip katılımcılardan daha olumlu olduğu anlaşılmıştır. İletişim aracı olarakreklama yönelik genel tutumlarda orta ve yüksek muhafazakarlık gruplarındaki katılımcılar arasında ise anlamlı bir fark bulunmamaktadır (Tablo 3).

Tablo 3: Çoklu Karşılaştırmalar Tablosu (Lsd)- İletişim

Aracı Olarak Reklama Yönelik Genel Tutum

\begin{tabular}{|c|c|c|c|c|c|c|c|}
\hline \multirow{2}{*}{$\begin{array}{l}\text { Bağımlı } \\
\text { Değişken }\end{array}$} & \multirow{2}{*}{$\begin{array}{l}\text { (l) } \\
\text { Muhafazakarlık } \\
\text { Düzeyi }\end{array}$} & \multirow{2}{*}{$\begin{array}{l}\text { (J) } \\
\text { Muhafazakarlık } \\
\text { Düzeyi }\end{array}$} & \multirow{2}{*}{$\begin{array}{c}\text { Mean } \\
\text { Difference } \\
(I-J)\end{array}$} & \multirow{2}{*}{$\begin{array}{l}\text { Std. } \\
\text { Error }\end{array}$} & \multirow{2}{*}{ Sig. } & \multicolumn{2}{|c|}{ 95\% Confidence Interval } \\
\hline & & & & & & $\begin{array}{l}\text { Lower } \\
\text { Bound }\end{array}$ & $\begin{array}{l}\text { Upper } \\
\text { Bound }\end{array}$ \\
\hline \multirow{6}{*}{$\begin{array}{l}\text { İletişim } \\
\text { Aracı Olarak } \\
\text { Reklama } \\
\text { Yönelik Genel } \\
\text { Tutum }\end{array}$} & \multirow{2}{*}{ Düşük } & Orta & $-0,703^{*}$ & 0,127 & 0,000 & $-0,953$ & $-0,452$ \\
\hline & & Yüksek & $-0,474^{*}$ & 0,115 & 0,000 & $-0,699$ & $-0,248$ \\
\hline & \multirow{2}{*}{ Orta } & Düşük & $0,703^{*}$ & 0,127 & 0,000 & 0,452 & 0,953 \\
\hline & & Yüksek & 0,229 & 0,136 & 0,094 & $-0,039$ & 0,498 \\
\hline & \multirow[t]{2}{*}{ Yüksek } & Düşük & $0,474^{*}$ & 0,115 & 0,000 & 0,248 & 0,699 \\
\hline & & Orta & $-0,229$ & 0,136 & 0,094 & $-0,498$ & 0,039 \\
\hline
\end{tabular}

\subsection{Muhafazakarlık Düzeyine Göre Kurum Olarak Reklamcılığa Yönelik Genel Tutumlar}

Katılımcıların muhafazakarlık düzeyine göre kurum olarak reklamcılığa yönelikgenel tutumları arasında bir fark olup olmadığını ve eğer fark varsa bunun hangi gruplar arasında olduğunu ortaya koymak amacıyla Tek Yönlü ANOVA analizi uygulanmıștır. Analiz sonucunda elde edilen p değeri (Sig) 0,05'ten küçük olduğu için kurum olarak reklamcılığa yönelik genel tutumlar açısından katılımcıların muhafazakarlık düzeylerine göre gruplar arasında farklılık olduğu söylenebilir (Tablo 4). 
Tablo 4: Kurum Olarak Reklamcılığa Yönelik Genel Tutumlar

\begin{tabular}{|l|c|c|c|c|c|}
\hline $\begin{array}{l}\text { Kurum Olarak Reklamcılığa } \\
\text { Yönelik Tutum }\end{array}$ & $\begin{array}{c}\text { Sum of } \\
\text { Squares }\end{array}$ & df & $\begin{array}{c}\text { Mean } \\
\text { Square }\end{array}$ & F & Sig. \\
\hline Between Groups & 4,096 & 2 & 2,048 & 3,348 &, 037 \\
\hline Within Groups & 149,243 & 244 &, 612 & & \\
\hline Total & 153,339 & 246 & & & \\
\hline
\end{tabular}

Çoklu Karşılaştırmalar Tablosuna göre orta ve yüksek muhafazakarlık puanına sahip katılımcıların kurum olarak reklamcılığa yönelik genel tutumlarının, düşük muhafazakarlık puanına sahip katılımcılardan daha olumlu olduğu tespit edilmiştir. Kurum olarak reklamcılığa yönelik genel tutumlar söz konusu olduğunda orta ve yüksek muhafazakarlık gruplarındaki katılımcılar arasında ise anlamlı bir fark bulunmamaktadır (Tablo 5).

Tablo 5: Çoklu Karşıllaştırmalar Tablosu (Lsd)- Kurum Olarak Reklamcilığa Yönelik Genel Tutum

\begin{tabular}{|c|c|c|c|c|c|c|c|}
\hline \multirow{2}{*}{$\begin{array}{l}\text { Bağımlı } \\
\text { Değişken }\end{array}$} & \multirow{2}{*}{$\begin{array}{l}\text { (I) } \\
\text { Muhafazakarlık } \\
\text { Düzeyi }\end{array}$} & \multirow{2}{*}{$\begin{array}{l}\text { (J) } \\
\text { Muhafazakarlık } \\
\text { Düzeyi }\end{array}$} & \multirow{2}{*}{$\begin{array}{c}\text { Mean } \\
\text { Difference } \\
\text { (I-J) }\end{array}$} & \multirow{2}{*}{$\begin{array}{l}\text { Std. } \\
\text { Error }\end{array}$} & \multirow{2}{*}{ Sig. } & \multicolumn{2}{|c|}{ 95\% Confidence Interval } \\
\hline & & & & & & $\begin{array}{l}\text { Lower } \\
\text { Bound }\end{array}$ & $\begin{array}{l}\text { Upper } \\
\text { Bound }\end{array}$ \\
\hline \multirow{6}{*}{$\begin{array}{l}\text { Kurum Olarak } \\
\text { Reklamcılığa } \\
\text { Yönelik Tutum }\end{array}$} & \multirow{2}{*}{ Düşük } & Orta & $-0,288^{*}$ & 0,128 & 0,025 & $-0,540$ & $-0,037$ \\
\hline & & Yüksek & $-0,231^{*}$ & 0,115 & 0,046 & $-0,458$ & $-0,004$ \\
\hline & \multirow{2}{*}{ Orta } & Düşük & $0,288^{*}$ & 0,128 & 0,025 & 0,037 & 0,540 \\
\hline & & Yüksek & 0,057 & 0,137 & 0,676 & $-0,213$ & 0,327 \\
\hline & \multirow{2}{*}{ Yüksek } & Düşük & $0,231^{*}$ & 0,115 & 0,046 & 0,004 & 0,458 \\
\hline & & Orta & $-0,057$ & 0,137 & 0,676 & $-0,327$ & 0,213 \\
\hline
\end{tabular}

\subsection{Muhafazakarlık Düzeyine Göre Ford Kamyon Reklamına Yönelik Tutumlar}

Katılımcıların muhafazakarlık düzeyine göre Ford Kamyon reklamına yönelik genel tutumları arasında bir fark olup olmadığını ve eğer fark varsa bunun hangi gruplar arasında olduğunu ortaya koymak amacıyla Tek Yönlü ANOVA analizi yapılmıştır. Elde edilen sonuçlar muhafazakarlık grupları arasında Ford Kamyon reklamına yönelik tutumlarda farklılık olduğunu ortaya koymaktadır (Tablo 6).

Tablo 6: Ford Kamyon Reklamına Yönelik Tutumlar

\begin{tabular}{|l|c|c|c|c|c|}
\hline $\begin{array}{l}\text { Ford Kamyon } \\
\text { Reklamı Tutum }\end{array}$ & $\begin{array}{c}\text { Sum of } \\
\text { Squares }\end{array}$ & df & $\begin{array}{c}\text { Mean } \\
\text { Square }\end{array}$ & F & Sig. \\
\hline $\begin{array}{l}\text { Between } \\
\text { Groups }\end{array}$ & 17,693 & 2 & 8,846 & 9,511 &, 000 \\
\hline Within Groups & 229,730 & 247 &, 930 & & \\
\hline Total & 247,423 & 249 & & & \\
\hline
\end{tabular}

Çoklu Karşılaştırmalar Tablosuna göre orta ve yüksek muhafazakarlık puanına sahip katılımcıların Ford Kamyon reklamına yönelik tutumlarının, düşük muhafazakarlık puanına sahip katılımcılardan daha olumlu olduğu ortaya konmuştur. Ford Kamyon reklamına yönelik tutumlarda orta ve yüksek muhafazakarlık gruplarındaki katılımcılar arasında ise anlamlı bir fark bulunmadı̆̆ı anlaşılmıştır (Tablo 7). 
Tablo 7: Çoklu Karşılaştırmalar Tablosu (Tamhene)- Ford

Kamyon Reklamına Yönelik Tutumlar

\begin{tabular}{|c|c|c|c|c|c|c|c|}
\hline \multirow{2}{*}{$\begin{array}{l}\text { Bağımıı } \\
\text { Değişken }\end{array}$} & \multirow{2}{*}{$\begin{array}{l}\text { (l) } \\
\text { Muhafazakarlık } \\
\text { Düzeyi }\end{array}$} & \multirow{2}{*}{$\begin{array}{l}\text { (J) } \\
\text { Muhafazakarlık } \\
\text { Düzeyi }\end{array}$} & \multirow{2}{*}{$\begin{array}{c}\text { Mean } \\
\text { Difference } \\
\text { (I-J) }\end{array}$} & \multirow{2}{*}{$\begin{array}{l}\text { Std. } \\
\text { Error }\end{array}$} & \multirow{2}{*}{ Sig. } & \multicolumn{2}{|c|}{ 95\% Confidence Interval } \\
\hline & & & & & & $\begin{array}{l}\text { Lower } \\
\text { Bound }\end{array}$ & $\begin{array}{l}\text { Upper } \\
\text { Bound }\end{array}$ \\
\hline \multirow{6}{*}{$\begin{array}{l}\text { Ford } \\
\text { Kamyon } \\
\text { Reklamı } \\
\text { Tutum }\end{array}$} & \multirow{2}{*}{ Düşük } & Orta & ${ }^{*}-0,342$ & 0,136 & 0,040 & $-0,671$ & $-0,012$ \\
\hline & & Yüksek & ${ }^{*}-0,607$ & 0,155 & 0,000 & $-0,983$ & $-0,232$ \\
\hline & \multirow{2}{*}{ Orta } & Düşük & ${ }^{*} 0,342$ & 0,136 & 0,040 & 0,012 & 0,671 \\
\hline & & Yüksek & $-0,265$ & 0,175 & 0,347 & $-0,689$ & 0,159 \\
\hline & \multirow{2}{*}{ Yüksek } & Düşük & ${ }^{*} 0,607$ & 0,155 & 0,000 & 0,232 & 0,983 \\
\hline & & Orta & 0,265 & 0,175 & 0,347 & $-0,159$ & 0,689 \\
\hline
\end{tabular}

4.4.1. Kadın Katılımcıların Muhafazakarlık Düzeyine Göre Ford Kamyon Reklamına Yönelik Tutumları

Cinsiyet değişkenine göre Ford Kamyon reklamına yönelik tutumlarda katılımcıların muhafazakarlık düzeyi açısından gruplar arasında bir fark olup olmadığını ve eğer fark varsa bunun hangi gruplar arasında olduğunu ortaya koymak amacıyla, veriler cinsiyete göre sınıflandırılarak (split file yöntemi ile), Tek Yönlü ANOVA analizi uygulanmıștır.

Tablo 8'de yer alan p değeri (Sig) 0,05'ten küçük olduğu ( $p=0,001)$ için kadın katılımcıların muhafazakarlık düzeylerine göre gruplar arasında Ford Kamyon reklamına yönelik tutumları açısından farklılık olduğu anlaşılmıștır.

Tablo 8: Kadın Katılımcıların Ford Kamyona Yönelik Tutumları

\begin{tabular}{|l|c|c|c|c|c|}
\hline $\begin{array}{l}\text { Ford Kamyon Reklamı } \\
\text { Tutum (Kadın Katılımcılar) }\end{array}$ & $\begin{array}{c}\text { Sum of } \\
\text { Squares }\end{array}$ & df & $\begin{array}{c}\text { Mean } \\
\text { Square }\end{array}$ & F & Sig. \\
\hline Between Groups & 10,210 & 2 & 5,105 & 7,597 &, 001 \\
\hline Within Groups & 81,978 & 122 &, 672 & & \\
\hline Total & 92,188 & 124 & & & \\
\hline
\end{tabular}

Çoklu Karşılaştırmalar Tablosuna göre orta ve yüksek muhafazakarlık puanına sahip kadın katılımcıların Ford Kamyon reklamına yönelik tutumlarının, düşük muhafazakarlık puanına sahip katılımcılardan daha olumlu olduğu anlaşılmıştır. Ford Kamyon reklamına yönelik tutumlarda orta ve yüksek muhafazakarlık gruplarındaki kadın katılımcılar arasında ise anlamlı bir fark bulunmadığı tespit edilmiştir (Tablo 9). 
Tablo 9: Çoklu Karşılaştırmalar Tablosu (Lsd)- Kadın

Katılımcıların Ford Kamyona Yönelik Tutumları

\begin{tabular}{|c|c|c|c|c|c|c|c|}
\hline \multirow{2}{*}{$\begin{array}{l}\text { Bağımlı } \\
\text { Değişken }\end{array}$} & \multirow{2}{*}{$\begin{array}{l}\text { (I) } \\
\text { Muhafazakarlık } \\
\text { Düzeyi }\end{array}$} & \multirow{2}{*}{$\begin{array}{l}\text { (J) } \\
\text { Muhafazakarlık } \\
\text { Düzeyi }\end{array}$} & \multirow{2}{*}{$\begin{array}{l}\text { Mean } \\
\text { Difference } \\
\text { (I-J) }\end{array}$} & \multirow{2}{*}{$\begin{array}{l}\text { Std. } \\
\text { Error }\end{array}$} & \multirow{2}{*}{ Sig. } & \multicolumn{2}{|c|}{ 95\% Confidence Interva } \\
\hline & & & & & & $\begin{array}{l}\text { Lower } \\
\text { Bound }\end{array}$ & $\begin{array}{l}\text { Upper } \\
\text { Bound }\end{array}$ \\
\hline \multirow{6}{*}{$\begin{array}{l}\text { Ford Kamyon } \\
\text { Reklamı } \\
\text { Tutum (Kadın } \\
\text { Katılımclar) }\end{array}$} & \multirow{2}{*}{ Düşük } & Orta & $-0,455^{\star}$ & 0,204 & 0,027 & $-0,858$ & $-0,053$ \\
\hline & & Yüksek & $-0,624^{*}$ & 0,163 & 0,000 & $-0,947$ & $-0,301$ \\
\hline & \multirow{2}{*}{ Orta } & Düşük & $0,455^{\star}$ & 0,204 & 0,027 & 0,053 & 0,858 \\
\hline & & Yüksek & $-0,168$ & 0,203 & 0,408 & $-0,570$ & 0,233 \\
\hline & \multirow{2}{*}{ Yüksek } & Düşük & $0,624^{*}$ & 0,163 & 0,000 & 0,301 & 0,947 \\
\hline & & Orta & 0,168 & 0,203 & 0,408 & $-0,233$ & 0,570 \\
\hline
\end{tabular}

${ }^{*} P \leq 0,05$

\subsubsection{Erkek Katılımcıların Muhafazakarlık Düzeyine Göre Ford Kamyon Reklamına Yönelik Tutumları}

Tablo 10'da yer alan ANOVA Tablosu Erkek katılımcıların Ford Kamyon reklamına yönelik tutumlarında muhafazakarlık düzeyi açısından bir farklılık olup olmadığını test etmektedir. Bu tabloda yer alan p değeri (Sig) 0,05'ten büyük olduğu $(p=0,195)$ için erkek katılımcıların muhafazakarlık düzeylerine göre gruplar arasında Ford Kamyon reklamına yönelik tutumları açısından farklılık olmadığı tespit edilmiştir.

Tablo 10: Erkek Katılımcıların Ford Kamyona Yönelik Tutumları

\begin{tabular}{|l|c|c|c|c|c|}
\hline $\begin{array}{l}\text { Ford Kamyon Reklamı } \\
\text { Tutum (Erkek Katılımcılar) }\end{array}$ & $\begin{array}{c}\text { Sum of } \\
\text { Squares }\end{array}$ & df & $\begin{array}{c}\text { Mean } \\
\text { Square }\end{array}$ & F & Sig. \\
\hline Between Groups & 3,701 & 2 & 1,851 & 1,659 &, 195 \\
\hline Within Groups & 136,073 & 122 & 1,115 & & \\
\hline Total & 139,774 & 124 & & & \\
\hline
\end{tabular}

\subsection{Ford kamyon reklamında rahatsız olunan unsurlar}

Anket çalışması sırasında katılımcılara yönlendirilen sorulardan bir tanesi de izledikleri Ford Kamyon reklamında kendilerini rahatsız eden bir unsurun olup olmadığıdır. Bu doğrultuda 111 adet unsur katılımcılar tarafından dile getirilmiştir. Tüm katılımcı görüşleri ele alındığında Ford Kamyon reklamında en yüksek oranda rahatsız olunan öğe kadının takı ve makyajıdır (\%21,6, n=24). Reklamın gerçekçi olmadığı $(\% 13,5, n=15)$, reklamdaki kadına erkek rolünün dayatıldığı $(\% 10,8$, $n=12)$ ve şoförlük mesleğinin kadına uygun bir meslek olmadığına $(\% 7,2, n=8)$ dair değerlendirmeler Ford Kamyon reklamında katılımcıları rahatsız eden unsurlar olarak tespit edilmiştir. (Tablo 11)

Tablo 11: Ford Kamyon Reklaminda Rahatsiz Olunan Unsurlar

\begin{tabular}{|l|c|c|l|c|c|}
\hline Rahatsız Olunan Unsurlar & $\mathbf{N}$ & $\mathbf{\%}$ & Rahatsız Olunan Unsurlar & N & \% \\
\hline Makyaj-Takı & 24 & 22 & Tavla görüntüleri & 3 & 2,7 \\
\hline Gerçekçi değil & 15 & 14 & Yapmacıklık & 3 & 2,7 \\
\hline $\begin{array}{l}\text { Kadına erkek rolü verilmesi } \\
\text { (toplumsal cinsiyet dayatmaları) }\end{array}$ & 12 & 11 & Kadının çalışması & 2 & 1,8 \\
\hline Kadına uygun değil (Kadın şoför olamaz) & 8 & 7,2 & Kadının özgüveni & 2 & 1,8 \\
\hline Marka ön planda & 8 & 7,2 & Yerellik & 2 & 1,8 \\
\hline Ürün geri planda & 7 & 6,3 & Duygu sömürüsü & 1 & 0,9 \\
\hline
\end{tabular}




\begin{tabular}{|l|c|c|l|c|c|}
\hline Rahatsız Olunan Unsurlar & N & \% & Rahatsız Olunan Unsurlar & N & \% \\
\hline Erkeksi & 4 & 3,6 & Etik değil & 1 & 0,9 \\
\hline Kadının başörtüsü & 4 & 3,6 & Kadının gülmesi & 1 & 0,9 \\
\hline Kadının kamyon kullanması & 4 & 3,6 & Özel bir gün için olması & 1 & 0,9 \\
\hline Reklamda kadın kullanıması & 4 & 3,6 & Samimiyetsiz & 1 & 0,9 \\
\hline Kadının konuşmaları & 3 & 2,7 & Süre uzun & 1 & 0,9 \\
\hline Toplam & & & & 111 & 100 \\
\hline
\end{tabular}

4.5.1. Muhafazakarlık Düzeyine Göre Ford Kamyon Reklamında Rahatsız Olunan Unsurlar

Ford Kamyon reklamında katılımcıların rahatsızlık duydukları unsurlar düşük, orta ve yüksek muhafazakarlık gruplarına göre de analiz edilmiştir. Düşük muhafazakarlık grubuna dahil olan katılımcılar Ford Kamyon reklamında en yüksek oranda reklamdaki ana kadın karaktere toplumsal cinsiyet rolleri bağlamında erkek rollerinin atfedilmiş olmasından $(\% 24,4, \mathrm{n}=11)$ ve reklamın gerçekçi olmamasından $(\% 24,4, \mathrm{n}=11)$ rahatsızlık duymuşlardır. Reklamdaki kadının başörtüsü $(\% 6,7$, $\mathrm{n}=3)$, reklamda markanın ön planda olması $(\% 6,7, \mathrm{n}=3)$, kadının takı ve makyajı $(\% 6,7, n=3)$, ürünün geri planda olması $(\% 6,7, n=3)$ da muhafazakarlık puanı düşük katılımcılar tarafından yüksek oranda ifade edilen rahatsızlık verici unsurlar arasında yer almıștır (Tablo 12).

Tablo 12: Düşük Muhafazakarlık Grubu Ford Kamyon Reklamında Rahatsız Olunan Unsurlar

\begin{tabular}{|l|c|c|}
\hline Rahatsız Olunan Unsurlar & N & $\mathbf{\%}$ \\
\hline Kadına erkek rolü verilmesi (toplumsal cinsiyet dayatmaları) & 11 & 24,4 \\
\hline Gerçekçi değil & 11 & 24,4 \\
\hline Kadının başörtüsü & 3 & 6,7 \\
\hline Marka ön planda & 3 & 6,7 \\
\hline Makyaj -Takı & 3 & 6,7 \\
\hline Ürün geri planda & 3 & 6,7 \\
\hline Diğer & 11 & 24 \\
\hline Toplam & 45 & 100 \\
\hline
\end{tabular}

Orta muhafazakarlık grubunda yer alan katılımcılar arasında reklamda markanın ön planda olmasından $(\% 15, \mathrm{n}=3)$ ve ürünün ön planda olmasından duyulan rahatsızlık oranı birbirine eșittir $(\% 15, n=3)$. Reklamdaki tavla oynama sahneleri $(\% 10, n=2)$, kadının takı ve makyajı $(\% 10, n=2)$ ve reklamın gerçekçi olmayışı $(\% 10, n=2)$ orta düzey muhafazakarlık grubu katılımcıları tarafından yüksek oranda dile getirilen diğer rahatsız edici unsurlardır (Tablo 13).

Tablo 13: Orta Muhafazakarlık Grubu Ford Kamyon Reklamında Rahatsız Olunan Unsurlar

\begin{tabular}{|l|c|c|}
\hline Rahatsız Olunan Unsurlar & N & \% \\
\hline Marka ön planda & 3 & 15,0 \\
\hline Ürün geri planda & 3 & 15,0 \\
\hline Tavla görüntüleri & 2 & 10,0 \\
\hline Makyaj-Takı & 2 & 10,0 \\
\hline Gerçekçi değil & 2 & 10,0 \\
\hline Diğer & 8 & 40 \\
\hline Toplam & 20 & 100 \\
\hline
\end{tabular}


Reklamdaki Hanımağa karakterinin makyaj ve takıları (\%40,4, n=19) yüksek muhafazakarlık grubunca en yüksek oranda dile getirilen unsurdur. Bunu şoförlük mesleğinin kadına uygun bir iș olmadığı $(\% 17, n=8)$ ve kadının kamyon kullanmasından duyulan rahatsızlık $(\% 6,4, \mathrm{n}=3)$ ifadeleri takip etmiștir. Kadının davranışlarının erkeksi oluşu (\%4,3, n=2), reklamın gerçek dişı oluşu (\%4,3, n=2), kadının çalışması $(\% 4,3, \mathrm{n}=2)$, markanın ön planda olması $(\% 4,3, \mathrm{n}=2)$ ve reklamda kadın kullanılması $(\% 4,3, n=2)$ da muhafazakarlık düzeyi yüksek katılımcıları rahatsız etmiştir (Tablo 14).

Tablo 14: Yüksek Muhafazakarlık Grubu Ford Kamyon Reklamında Rahatsız Olunan Unsurlar

\begin{tabular}{|l|c|c|}
\hline Rahatsız Olunan Unsurlar & N & \% \\
\hline Makyaj- Takı & 19 & 40,4 \\
\hline Kadına uygun değil (Kadın şoför olamaz) & 8 & 17,0 \\
\hline Kadının kamyon kullanması & 3 & 6,4 \\
\hline Erkeksi & 2 & 4,3 \\
\hline Gerçekçi değil & 2 & 4,3 \\
\hline Kadının çalışması & 2 & 4,3 \\
\hline Marka ön planda & 2 & 4,3 \\
\hline Reklamda kadın kullanılması & 2 & 4,3 \\
\hline Diğer & 6 & 14,7 \\
\hline Toplam & 46 & 100 \\
\hline
\end{tabular}

Toplumsal cinsiyet rolleri açısından kadına erkek rolü atfedilmesinden düşük muhafazakarlık puanına sahip katılımcılar diğer gruplara oranla en yüksek oranda rahatsızlık duyarken, yüksek muhafazakarlık düzeyindeki katılımcılar ise en yüksek oranda kadının takı ve makyajından rahatsızlık duymuşlardır. Kadının başörtüsünden rahatsız olduğunu ifade eden katılımcıların orta ve düşük muhafazakarlık grubuna dahil olduğu anlaşılmıştır. Kadının kamyon kullanmasından ve şoförlügüun kadınlara uygun bir meslek olmamasından dolayı reklamdan rahatsızlık duyduğunu belirtenler ise sadece yüksek muhafazakarlık puanına sahip katılımcılardır.

\subsection{Ford Kamyon Reklamında Hoşa Giden Unsurlar}

Anket çalışması kapsamında katılımcılara Ford Kamyon reklamında en çok hoşlarına giden unsurun ne olduğu sorulmuştur. Hoşa giden unsurlar analiz edilirken ankete katılan kişi sayısı değil, ifade edilen unsur sayısı esas alınmıştır. Dolayısıyla verilen yanıtlar incelendiğinde toplam 253 adet hoşa giden unsurun dile getirildiği anlaşılmıştır. Tüm katılımcı görüşleri ele alındığında Ford Kamyon reklamında katılımcıların en yüksek oranda hoşlarına giden unsur kadının başarısıdır (\%17, $\mathrm{n}=43)$. Reklamdaki "kadın isterse her şeyi başarabilir" mesajı $(\% 11,9, \mathrm{n}=30)$, eşler arasındaki dayanışma $(\% 11,9, \mathrm{n}=30)$ ve kadının çalışması $(\% 9,5, \mathrm{n}=24)$ reklamda katılımcıların yüksek oranda beğenisini kazanan öğelerdir (Tablo 15).

Tablo 15: Ford Kamyon Reklamında Hoșa Giden Olunan Unsurlar

\begin{tabular}{|l|c|c|l|c|c|}
\hline Hoşa Giden Unsurlar & N & \% & Hoşa Giden Unsurlar & N & \% \\
\hline Kadının başarısı & 43 & 17 & Kadının özgürlüğü & 3 & 1,2 \\
\hline Kadın isterse her şeyi yapar mesajı & 30 & 11,9 & Kamyon (araç) & 3 & 1,2 \\
\hline Eşler arası dayanışma & 30 & 11,9 & Türk halkına uygun & 3 & 1,2 \\
\hline Kadının çalışması & 24 & 9,5 & Ford markası & 2 & 0,8 \\
\hline Kadının özgüveni & 16 & 6,3 & Kadının birey oluşu & 2 & 0,8 \\
\hline
\end{tabular}




\begin{tabular}{|l|c|c|l|c|c|}
\hline Hoşa Giden Unsurlar & N & $\mathbf{\%}$ & Hoşa Giden Unsurlar & N & \% \\
\hline Kadının kamyon kullanması & 15 & 5,9 & Kadının gülüşü & 2 & 0,8 \\
\hline $\begin{array}{l}\text { Kadının genelde erkeklerin } \\
\text { yaptığı işi üstlenmesi }\end{array}$ & 14 & 5,5 & Kadınlara yönelik olması & 2 & 0,8 \\
\hline Cinsiyet eşitliği & 13 & 5,1 & Makyaj - Takı & 2 & 0,8 \\
\hline Örnek-eğitici-teşvik & 12 & 4,7 & Slogan & 2 & 0,8 \\
\hline Reklamın çekim tekniği & 8 & 3,2 & Akıcı & 1 & 0,4 \\
\hline Samimi - doğal & 8 & 3,2 & Herkese hitap etme & 1 & 0,4 \\
\hline Doğa manzaraları & 5 & 2 & İşi büyütmeleri & 1 & 0,4 \\
\hline Gerçek hikaye & 5 & 2 & Kadının geleneksel görüntüsü & 1 & 0,4 \\
\hline Marka geri planda & 4 & 1,6 & Özel bir gün için olması & 1 & 0,4 \\
\hline Toplam & & & & 253 & 100 \\
\hline
\end{tabular}

\subsubsection{Muhafazakarlık Düzeyine Göre Ford Kamyon Reklamında Hoşa Giden Unsurlar}

Katılımcılara Ford Kamyon reklamında en çok hoşlandıkları unsurlar düşük, orta ve yüksek muhafazakarlık gruplarına göre de analiz edilmiştir. Reklamdaki kadın isterse her şeyi başarabilir mesajı (\%17, $n=16)$ ve kadının başarısı $(\% 14,9, n=14)$ muhafazakarlık düzeyi düşük olan katılımcıların hoşlarına giden unsurlar arasında öne çıkmaktadır. Reklamı toplumsal cinsiyet rolleri açısından değerlendiren bu katılımcıların aynı zamanda reklamdaki kadının genelde erkeklerin yaptığı işi üstlenmesini $(\% 8,5, n=8)$, cinsiyet eşitliği vurgusunu $(\% 7,4, n=7)$ ve kadınının çalışıyor olmasını $(\% 6,4, \mathrm{n}=6)$ da beğendikleri anlaşılmıştır. Reklamın çekim tekniğine $(\% 6,4, n=6)$ yönelik olumlu değerlendirmeler ile reklamın samimi ve doğal oluşu $(\% 6,4, n=6)$ da düşük muhafazakarlık grubundaki katılımcılarca dile getirilen unsurlar arasındadır (Tablo 16).

Tablo 16: Düşük Muhafazakarlık Grubu Ford Kamyon Reklamında Hoşa Giden Unsurlar

\begin{tabular}{|l|c|c|}
\hline Hoşa Giden Unsurlar & N & \% \\
\hline Kadın isterse her şeyi yapar mesajı & 16 & 17,0 \\
\hline Kadının başarısı & 14 & 14,9 \\
\hline Kadının genelde erkeklerin yaptığı işi üstlenmesi & 8 & 8,5 \\
\hline Cinsiyet eşitliği & 7 & 7,4 \\
\hline Kadının çalışması & 6 & 6,4 \\
\hline Reklamın çekim tekniği & 6 & 6,4 \\
\hline Samimi - doğal & 6 & 6,4 \\
\hline Diğer & 31 & 33 \\
\hline Toplam & 94 & 100 \\
\hline
\end{tabular}

Orta muhafazakarlık grubunda yer alan katılımcıların en yüksek oranda hoşlarına giden unsur reklamdaki kadının başarısıdır (\%19, n=12). Eşler arasındaki dayanışma $\% 12,7(n=8)$ oran ile orta muhafazakarlık grubunda yer alan katılımcılarca ikinci olarak en yüksek oranda ifade edilen hoşa giden unsurdur. Kadının isterse her şeyi yapabileceği mesajı $(\% 9,5, n=6)$, reklamın kadınlara örnek olan, teşvik edici ve eğitici bir reklam olması $(\% 9,5, \mathrm{n}=6)$, kadının çalışması $(\% 7,9, \mathrm{n}=5)$ ve cinsiyet eşitliliği $(\% 4,8, n=3)$ unsurları diğer hoșa giden unsurlar arasında yer almıștır (Tablo 17). 
Tablo 17: Orta Muhafazakarlık Grubu Ford Kamyon Reklamında Hoşa Giden Unsurlar

\begin{tabular}{|l|c|c|}
\hline Hoşa Giden Unsurlar & N & \% \\
\hline Kadının başarısı & 12 & 19,0 \\
\hline Esler arası dayanışma & 8 & 12,7 \\
\hline Kadın isterse her şeyi yapar mesajı & 6 & 9,5 \\
\hline Örnek-eğitici-teşvik & 6 & 9,5 \\
\hline Kadının çalışması & 5 & 7,9 \\
\hline Cinsiyet eşitliği & 3 & 4,8 \\
\hline Kadının özgüveni & 3 & 4,8 \\
\hline Diğer & 20 & 31,8 \\
\hline Toplam & 63 & 100 \\
\hline
\end{tabular}

Ford Kamyon reklamında hoşa giden unsurlar arasında eșler arasındaki dayanışma $(\% 22,3, n=21)$ yüksek muhafazakarlık grubunca en yüksek oranda dile getirilen unsurdur. Muhafazakarlık düzeyi yüksek olan katılımcılar tarafından dile getirilen diğer hoşa giden unsurlar arasında kadının başarısı $(\% 16, n=15)$, çalışması $(\% 13,8, n=13)$, özgüveni $(\% 10,6, n=10)$ ve kamyon kullanması $(\% 10,6, n=10)$ öne çıkmaktadır. Reklamdaki kadın isterse her şeyi yapar mesajı hoşa giden unsurlara arasında \%8,5 (n=8) orana sahiptir. Genelde erkeklerin yaptığı işi kadının üstlenmesi ise $\% 4,3(\mathrm{n}=4)$ oran ile yüksek muhafazakarlık grubundaki katılımcılar tarafından dile getirilmiștir (Tablo 18).

Tablo 18: Yüksek Muhafazakarlık Grubu Ford Kamyon Reklamında Hoşa Giden Unsurlar

\begin{tabular}{|l|c|c|}
\hline Hoşa Giden Unsurlar & N & \% \\
\hline Eşler arası dayanışma & 21 & 22,3 \\
\hline Kadının başarısı & 15 & 16,0 \\
\hline Kadının çalışması & 13 & 13,8 \\
\hline Kadının özgüveni & 10 & 10,6 \\
\hline Kamyon kullanması & 10 & 10,6 \\
\hline Kadın isterse her şeyi yapar mesajı & 8 & 8,5 \\
\hline Kadının genelde erkeklerin yaptığı işi üstlenmesi & 4 & 4,3 \\
\hline Diğer & 81 & 13,9 \\
\hline Toplam & 96 & 100 \\
\hline
\end{tabular}

Reklamdaki kadın isterse her şeyi başarabilir mesajı tüm muhafazakarlık grupları içinde en yüksek oranda düşük muhafazakarlık grubundaki katılımcılar arasında beğenilirken, bu gruba dahil olan katılımcılar aynı zamanda reklamı toplumsal cinsiyet rolleri açısından değerlendirmişler, reklamdaki kadının genelde erkeklerin yaptığı bir işi üstlenmesi ve cinsiyet eşitliği unsurlarını da diğer gruplardan daha yüksek oranda dile getirmişlerdir. Muhafazakarlık düzeyi yükseldikçe hoşa giden unsurlarda öne çıkan bir öğe ise eşler arası dayanışmadır. Orta muhafazakarlık grubunda bu unsur ikinci sırada yer alırken, yüksek muhafazakarlık grubunda ise en yüksek oranda hoşa giden unsur olarak belirlenmiştir. Ayrıca kadının çalışmasına yönelik olumlu değerlendirmelerin en yüksek oranda yüksek muhafazakarlık grubu tarafından yapıldığı anlaşılmıştır.

\section{Sonuç ve Değerlendirme}

Hem siyasi bir ideoloji hem de kişisel bir eğilim, bir tutum olarak tanımlanan muhafazakarlık özellikle günümüz Türkiye'sinde sıklıkla tartışılan bir kavram halini almıştır. 1980'li yıllardan bu yana Türkiye'nin yaşamakta olduğu değişim ve dönüşüm süreciyle birlikte, tüketim toplumunun ayrılmaz bir parçası olan 
reklamlar ile bireylerin sahip oldukları muhafazakâr tutumlar arasında nasıl bir ilişki olduğu sorusu bu araștırmanın ana çıkış noktasını oluşturmuştur. Bu bağlamda reklamlara, reklamcılığa ve maruz kalınan belirli bir reklama yönelik izleyici tutumlarında muhafazakarlık düzeyine göre bir farklılaşmanın olup olmadığı aydınlatılmaya çalışılmıştır.

Araştırma sonuçları orta ve yüksek muhafazakarlık grubunda yer alan katılımcıların reklamlara ve reklamcılığa yönelik genel tutumlarının düşük muhafazakarlık puanına sahip katılımcılardan daha olumlu yönde olduğunu ortaya koymuştur. $\mathrm{Bu}$ durum belirli bir reklam söz konusu olduğunda da geçerliliğini korumuş, Ford Kamyon reklamına yönelik tutumların ağırlıklı olarak orta ve yüksek muhafazakarlık puanına sahip katılımcılara ait olduğu anlaşılmıştır.

Türkiye'de 1980'li yıllardan itibaren neo-liberal ekonomi politikalarının kabul edilmesi ve tüketim topluma dönüşme süreci başlamış; 2000'li yıllardan sonra ise muhafazakarlık kapitalist sisteme iyice adapte olmuştur. Söz konusu Türkiye olduğunda bir yanda piyasa değerleri kabul görürken diğer yanda ise toplumun muhafazakâr bir eğilim içerisinde olduğu görülmektedir (Demirezen, 2015, 7879; Durak, 2013, 34; Yankaya, 2014, 16). Bu durumun yansımaları, bu araștırma kapsamında elde edilen bulgularda da karşımıza çıkmıştır. Muhafazakarlık düzeyi arttıkça reklama ve reklamcılığa yönelik genel tutumların olumlu yönde değişmesinin muhafazakarlığın kapitalist sisteme uyumunun bir yansıması olduğu söylenebilir.

Her ne kadar Ford Kamyon reklamına yönelik olumlu tutumlar muhafazakarlık düzeyi yükseldikçe olumlu yönde değişiyor olsa da bu değişimin cinsiyetler açısından incelenmesi aydınlatıcı veriler sunmuştur. Söz konusu reklamda kanıksanmış toplumsal cinsiyet rollerinin dișında bir kadın karakterin başrolde olmasından dolayı cinsiyet değişkenine göre veriler yeniden analiz edildiğinde, orta ve yüksek muhafazakarlık gruplarına dahil olan kadın katılımcıların Ford Kamyon reklamına yönelik daha olumlu bir tutuma sahip oldukları ancak erkek katılımcılar söz konusu olduğunda muhafazakarlık düzeyi açısından bir farklılığın olmadığı anlaşılmıştır. Kadın katılımcılar arasında muhafazakarlık düzeyi yükseldikçe Ford Kamyon reklamına yönelik olumlu tutumların artıyor olması "kadından şoför olamaz" dayatmasına muhafazakâr kadınların bir karşı duruşu olarak yorumlanabilir.

Ford Kamyon reklamında rahatsız olunan ve hoşa giden öğeler açısından da muhafazakarlık düzeyine göre farklılıklar olduğu anlaşılmıştır. Kadının toplumsal cinsiyet rolleri açısından kendisine uygun görülmeyen bir işte çalışması muhafazakarlık puanı yükseldikçe eleştiri alırken, muhafazakarlık puanı azaldıkça reklam daha geniş bir toplumsal çerçevede değerlendirilerek kadına erkeksi hareketlerin toplum tarafından dayatıldığı eleştirisi yapılmıştır. Reklamda kadının çalışmasına ve eşinin kadına destek olmasına yönelik olumlu değerlendirmeler ağırlıklı olarak muhafazakarlık düzeyi yüksek katılımcılarca dile getirilmiștir. Muhafazakarlık düzeyi azaldıkça hoşa giden unsurlar arasında cinsiyet eşitliği vurgusu ağırlık kazanmıştır. Özetle, söz konusu kadının toplumsal konumu olduğunda muhafazakarlık düzeyine göre hoşa giden ve rahatsız olunan unsurlar farklılaşabilmektedir. Muhafazakarlık düzeyi yükseldikçe kadına çizilen roller kanıksanmıș toplumsal cinsiyet rolleri sınırlarında kalırken muhafazakarlık düzeyi azaldığında ise erkek rollerinin kadına dayatılması eleştirilmekte ve cinsiyetler arası eşitlik vurgusu ön plana çıkmaktadır. 
Gelecek çalışmalarda evreni temsil gücü olan bir örneklem ile bu çalışma tekrarlanabilir. Ayrıca farklı içeriklere sahip reklamlar üzerinde muhafazakâr tutumların belirleyici olup olmadığı araştırılmalıdır.

\section{Notlar}

1 Ölçek maddeleri: iyi-kötü, etkili-etkisiz, değerli-değersiz, gerekli-gereksiz.

2 Ölçek maddeleri: ahlaklı değil- ahlaklı, aldatıcı- dürüst, sakıncalı-sakıncasız, samimiyetsiz- samimi.

3 Ölçek maddeleri: hoş değil- hoş, inandırıcı değil- inandıcı, etkileyici değil- etkileyici, ilgi çekici değil- ilgi çekici, bilgilendirici değil- bilgilendirici, anlaşılır değil-anaşılır, dikkat çekici değil-dikkat çekici, oldukça uygunsuz- oldukça uygun, ikna edici değil- ikna edici, genel olarak beğenmedim- genel olarak beğendim

${ }^{4}$ Muhafazakarlık Ölçeği Maddeleri: Dekolte kıyafetler, din adamlarının otoritesi, düşünce ve ifade özgülüğüne yönelik sansür, farklı dinden kişilerin evlenmesi, boşanmak, her insanın Müslüman olarak yaratılması, kuran kaideleri / kuralları, yılbaşı partileri, imam nikâhı, hayattaki her şeyi kaderin belirlemesi, eşcinsellik, erkeğin evlilik öncesi cinsel ilişki yaşaması, evrim teorisi, striptiz gösterisi, gençlerin itaatsiz davranışları, dini kurallara göre hukuk kanunlarının düzenlenmesi, Türk ırkının üstünlüğü, okulda ahlak eğitimi verilmesi, intihar, kürtaj, yetişkin kişilere alkol satışına yönelik kısıtlamalar, klasik müzik, cinsel içeriklere yönelik sansür, kadının evlilik öncesi cinsel ilişki yaşaması)

\section{Kaynakça}

Akıncl, M. (2012). Türk Muhafazakarlığı: Çok Partili Siyasal Hayattan 12 Eylül'e. İstanbul: Ötüken.

Akkaş, H.H. (2004). Muhafazakâr Düşünce ve Edmund Burke. Ankara: Kadim Yayınları.

Andrews, J. C., Durvasula, S. ve Netemeyer, R. G. (1994). Testing the cross-national applicability of US and Russian advertising belief and attitude measures. Journal of Advertising 23(1), 71-82.

Arkonaç, S.A. (1998). Sosyal Psikoloji. İstanbul: Alfa

Bir, A.A., Süher, H.K. ve Şener, G. (2015). An assessment of public attitudes toward advertising in-general in Turkey. Anadolu Üniversitesi Sosyal Bilimler Dergisi, 15(1), 43-54.

Bora, T. ve Onaran, B. (2004). Nostalji ve muhafazakarlık "mazi cenneti”. A.Çiğdem (Ed.) Modern Türkiye'de Siyasi Düşünce- Muhafazakarlık 5. Cilt, (s.234-260). İstanbul:İletişim.

Calfee, J. E. ve Ringold, D.J. (1988).Consumer skepticism and advertising regulation: what do the polls show?. NA-Advances in Consumer Research, 15, 244-248.

Çaha, Ö. (2001). Dört Akım Dört Siyaset. İstanbul: Zaman Kitap.

Demirezen, İ. (2015). Tüketim Toplumu ve Din. İstanbul: Ensar.

Donthu, N. (1998). A cross-sountry investigation of recall of and attitude toward advertsing. Journal of Advertising, 27 (2), 111-122.

Durak, Y. (2013). Emeğin Tevekkülü Konya'da İşçi-İşveren İlişkileri ve Dindarlı. İstanbul: İletişim.

Ergil, D. (1989). Muhafazakâr düşüncenin temelleri muhafazakârlık ve yeni muhafazakârlık. Ankara Üniversitesi SBF Dergisi, 41 (1-4), 269- 292.

Esmer, Y. (2012). Türkiye Değerler Atlası 2012 Değişimin Kültürel Sınırları. İstanbul: Bahçeşehir Üniversitesi Yayınları.

İnceoğlu, M. (2011). Tutum Algı İletişim. Ankara: Siyasal. 
Kalaycl, Ş. (2010). SPSS Uygulamalı Çok Değişkenli İstatistik Teknikleri (5. Bs.). Ankara: Asil Yayın Dağıtım.

Lutz, R.J. (1985).Affective and Cognitive Antecedents of Attitude Toward The Ad: A Conceptual Framework. L.F. Alwitt, A. A. Mitchell (Ed.). Psychological processes and advertising effects: theory, research and application (s. 45-63). USA: Lawrence Earlbaum Associates Hinsdale.

MacKenzie, S. B. ve Lutz, R. J. (1989). An Empirical Examination of The Structural Antecedents of Attitude Toward The Ad In An Advertising Pretesting Context. Journal of Marketing, 53, 48- 65.

Mehta, A. (2000). Advertising Attitudes And Advertising Effectiveness. Journal of Advertising Research, 40(3), 67-72.

Mollaer, F. (2009). Muhafazakarlığın İki Yüzü. İstanbul: Dergâh Yayınları.

Mollaer, F. (2011). Klasik Muhafazakarlıktan Tekno-Muhafazakarlığa: Tanım Sorunları, Temeller ve Değişimler. Doğu Batı, Türk Muhafazakarlığının Eleştirisi, 14 (58), 59-71.

Nisbet, R. (2011). Muhafazakarlık: Düş ve Gerçek (K.Bülbül ve M. F. Serenli, Çev.). (2. Bs). Ankara: Kadim Yayınları.

Özipek B.B. (2004). Muhafazakarlık, Devrim ve Türkiye. A.Çiğdem (Ed.), Modern Türkiye'de siyasi düşünce- muhafazakarlık 5. Cilt (s.66-83). İstanbul:İletişim.

Petrovici, D. ve Marinov, M. (2007). Determinants and Antecedents of General Attitudes Towards Advertising: A Study of Two EU Accession Countries. European Journal of Marketing, 41(3/4), pp.307-326.

Pollay, R. W. ve Mittal, B. (1993). Here's The Beef: Factors, Determinants And Segments in Consumer Criticism of Advertising. Journal of Marketing, 57(7), 99-114.

Safi, İ. (2007). Türkiye'de Muhafazakâr Siyaset ve Yeni Arayışlar. Ankara: Lotus

Sandage, C. H. ve Leckenby, J.D. (1980). Student Attitudes Toward Advertising: Institution vs. Instrument. Journal of Advertising, 9 (2), 29-44.

Şahin, K. (2010). Türkiye'de Gençliğin Muhafazakâr Eğilimleri. Doktora Tezi, Sakarya Üniversitesi, Sakarya.

Tavşancıl, E. (2006). Tutumların Ölçülmesi ve SPSS ile Veri Analizi. (3. Bs), Ankara: Nobel.

Vural, M. (2011). Siyaset Felsefesi Açısından Muhafazakarlık. İstanbul: Elis.

Wilson, G.D. (2013). The Psychology of Conservatism. New York: Routledge.

Yankaya, D. (2014). Yeni İslami Burjuvazi: Türk Modeli (M.E. Durmaz, Çev.). İstanbul: İletișim.

Yılmaz, H. (2006). Türkiye'de Muhafazakârlık: Aile, Din, Batı. Yayımlanmamış araştırma raporu, İstanbul:Boğaziçi Üniversitesi.

Yılmaz, H. (2012). Türkiye'de Muhafazakârlık: Aile, Din, Batı. Yayımlanmamış araştırma raporu, İstanbul: Boğaziçi Üniversitesi. 
